\title{
Control of Fusarium Crown and Root Rot of Tomato with Hypovirulent Binucleate Rhizoctonia in Soil and Rock Wool Systems
}

\author{
A. Muslim, United Graduate School of Agricultural Science, Gifu University, Yanagido 1-1, 501-1193 Gifu, Japan; \\ H. Horinouchi, Gifu Prefectural Research Institute for Agricultural Sciences, 729 Matamaru, Gifu 501-1152, Ja- \\ pan; and M. Hyakumachi, Laboratory of Plant Disease Science, Faculty of Agriculture, Gifu University, Yanagido \\ 1-1, 501-1193 Gifu, Japan
}

\begin{abstract}
Muslim, A., Horinouchi, H., and Hyakumachi, M. 2003. Control of Fusarium crown and root rot of tomato with hypovirulent binucleate Rhizoctonia in soil and rock wool systems. Plant Dis. 87:739-747.

Hypovirulent binucleate Rhizoctonia (HBNR) isolates L2, W1, W7, and Rhv7 were studied as potential antagonists of Fusarium crown and root rot of tomato (FCRR) caused by Fusarium oxysporum f. sp. radicis-lycopersici, in either soil or hydroponic rock wool systems. Reduction of FCRR on tomato by HBNR isolates was different depending on the isolate, days after inoculation of pathogen, and experiments. In the greenhouse soil system, HBNR isolates significantly $(P=0.01)$ reduced vascular discoloration and discoloration of total roots systems by 90 to $100 \%$ and by 73 to $89 \%$, respectively, in three experiments. Under field soil conditions, HBNR W1 provided significant $(P=0.05)$ reduction of vascular discoloration by $71 \%$. In the rock wool system, all HBNR isolates except L2 in experiment 1 significantly reduced $(P=0.05)$ vascular discoloration by 18 to $100 \%$ in four experiments. Plants treated with all HBNR isolates had foliar symptoms reduced by 41 to $100 \%$ in four experiments under the rock wool system. Application of HBNR also resulted in increases of marketable and total yields of tomatoes as much as 70 and $73 \%$, respectively, over the untreated plants. The number of colony forming units of $F$. oxysporum f. sp. radicis-lycopersici per gram fresh weight of roots and stems was significantly reduced $(P=0.05)$ in plants treated with HBNR in both soil and rock wool systems. HBNR was re-isolated at a high frequency from roots grown inside paper pots containing soil infested with HBNR, but rarely isolated from the roots grown in soil infested with only $F$. oxysporum f. sp. radicis-lycopersici outside the paper pots. HBNR was not re-isolated from the tomato stems. Stem extracts from HBNR-treated and pathogen-challenged plants in the rock wool system inhibited germination and production of budding cells of $F$. oxysporum f. sp. radicis-lycopersici.
\end{abstract}

Additional keyword: Lycopersicon esculentum

Fusarium oxysporum Schlechtend.:Fr. f. sp. radicis-lycopersici W.R. Jarvis \& Shoemaker (19), the causal agent of Fusarium crown and root rot (FCRR) of tomato (Lycopersicon esculentum Mill.), is an important disease worldwide and is responsible for yield losses in fields and commercial greenhouses. FCRR was first reported in Japan in 1969, where it caused 33 and $44 \%$ yield losses in Hokkaido and Kochi prefectures, respectively $(33,37)$. It then appeared in staked field tomatoes in California in 1971 (24). In the Cleveland area in 1976, the largest area of greenhouse

Corresponding author: M. Hyakumachi

E-mail: hyakumac@cc.gifu-u.ac.jp

Current address of A. Muslim: Department of Plant Pests and Diseases, Faculty of Agriculture, Sriwijaya University, Indralaya Campus, Palembang 30662, Indonesia.

Accepted for publication 23 December 2002.

Publication no. D-2003-0421-02R

(C) 2003 The American Phytopathological Society tomato production in the United States, yield losses due to FCRR were estimated at 20 to $50 \%$ (36).

Although tomato breeding lines resistant to FCRR are present in the cultivars Fla.7775 and Fla.7781 (38), they are not high-yielding cultivars. Recently, FCRR was effectively managed by application of the fungicides benomyl (30) and metam sodium (29). However, repeated application of such broad-spectrum fungicides may cause environmental problems and the appearance of fungicide-resistant strains of Fusarium (11). Thus, alternative control measures are needed as soon as possible.

Biological control has the potential to manage FCRR. Among the antagonists that have shown satisfactory degrees of control against this disease, Trichoderma harzianum (39), nonpathogenic Fusarium species (25), and the mycoparasite Pythium oligandrum (1) were the most common. Application of the biocontrol agent Trichoderma harzianum in combination with methyl bromide resulted in the most effective control against FCRR (39). In addition, Duffy and Defago (12) reported that zinc amendment improved biocontrol activity of Pseudomonas fluorescens against FCRR.

Researchers have used hypovirulent binucleate Rhizoctonia (HBNR) to control seedling damping-off caused by Rhizoctonia spp. in cotton, radish, wheat, and cucumber $(18,42,46)$, and by Pythium ultimum in Capsicum annuum and Celosia argentea (17). However, few data about the control of FCRR by HBNR are available. Louter and Edgington (25) reported control of FCRR by binucleate Rhizoctonia in tomato seedlings grown in growth pouch systems.

Colonization of host tissues is an important mechanism of crop protection with HBNR (6). This colonization triggers the production of host defense compounds such as peroxidases, glucanases, and chitinases (47). In addition, unlike many other biocontrol agents, HBNR can colonize the target area rapidly (45), survive in roots and soil for a long time $(9,44)$, and stimulate plant growth $(16,42,46)$.

Although the biological control of FCRR of tomato has been well studied in soil systems $(27,39)$, little work has been done on rock wool hydroponic systems. Rock wool hydroponic systems are being extensively used for growing tomato in greenhouses. Recent severe outbreaks of FCRR in rock wool systems in Gifu Prefecture, Japan (20) have shown the need to establish a biological control method for this disease in these systems.

Most experiments on the use of HBNR were evaluated for control of soilborne diseases at the seedling stage only. However, HBNR was reported to give longterm control of banded leaf and sheath blight in corn (34).

In this study, the ability of HBNR to protect tomato plants against FCRR throughout the growing period and their effects in reducing populations of $F$. oxysporum $\mathrm{f}$. $\mathrm{sp}$. radicis-lycopersici in roots and stems under soil and rock wool hydroponic systems were evaluated. To know the interaction between HBNR and $F$. $o x$ ysporum f. sp. radicis-lycopersici, the colonization of HBNR on roots and stems was studied. The effect of stem extracts from HBNR-treated and pathogen-challenged inoculated plants on the germination and proliferation of the pathogen was also determined. Previous results have been reported (31). 


\section{MATERIALS AND METHODS}

Organisms. Four isolates of HBNR: L2 (AG-Ba), W1, W7 (AG-A), and Rhv7 (unknown anastomosis group) were used as biocontrol agents. F. oxysporum f. sp. radicis-lycopersici isolate RJNI obtained from a diseased tomato plant with FCRR was used as inoculum of pathogen.

Plant. Tomato cv. House Momotaro, a popular cultivar that is susceptible to FCRR, was used throughout the experiments. All seeds were surface-disinfected with $1 \% \mathrm{NaOCl}$ for $15 \mathrm{~min}$ and rinsed three times in sterile distilled water prior to sowing.

Inoculum preparation. (1) HBNR for soil system. Each isolate of HBNR was grown on potato dextrose agar (PDA) for 3 days in the dark at $25^{\circ} \mathrm{C}$. Five mycelial disks $(5 \mathrm{~mm})$ of the isolate, taken from the edge of growth, were added to $100 \mathrm{~g}$ of moist autoclaved barley grains (1:1, wt/vol, dry barley grains/distilled water) contained in 500-ml Erlenmeyer flask. The cultures were incubated in the dark for 10 days at $25^{\circ} \mathrm{C}$ and shaken regularly to aid even colonization. The colonized grain was airdried for 7 days and stored at $4{ }^{\circ} \mathrm{C}$ until used. (2) HBNR for rock wool system. The HBNR was grown in potato dextrose broth (PDB) for 7 days at $25^{\circ} \mathrm{C}$ with shaking (115 rpm). The mycelial mass was then homogenized using a blender (Type $\mathrm{H}$, Teraoka Toyo Keisokuki Co., Ltd., Osaka, Japan) at 8,000 rpm for $5 \mathrm{~min}$ and diluted three times with sterile distilled water. The resulting mycelial suspensions were used as inoculum in the rock wool system. (3) Inoculum of $\mathrm{F}$. oxysporum $f$. $s p$. radicislycopersici isolate RJNI. Isolates RJNI were grown on PDA for 3 days in the dark at $25^{\circ} \mathrm{C}$. Five mycelial disks $(5 \mathrm{~mm})$ were transferred in $100 \mathrm{ml}$ of PDB and shaken at $115 \mathrm{rpm}$ for 7 days at $25^{\circ} \mathrm{C}$. To collect the microconidial inoculum of RJNI, the fungal culture was filtered through eight layers of sterile gauze, and the collected microconidial suspensions were used for inoculating into the soil and rock wool systems.

Assay of HBNR for control of FCRR in soil system. The HBNR-colonized grain was pulverized in a blender for $30 \mathrm{~s}$ ( 1 to 2 $\mathrm{mm}$ particle size) and mixed (2\%, wt/wt) with potting medium "Star Bed" (soilless peat-based potting medium, manufactured by JA Zennoh, Tokyo, Japan). The potting medium contains humus, peat, rock phosphate, and composted plant material. The nitrogen, phosphorus $\left(\mathrm{P}_{2} \mathrm{O}_{5}\right)$, and potassium $\left(\mathrm{K}_{2} \mathrm{O}\right)$ contents of the potting medium were 200:1,500:200 mg liter ${ }^{-1}$. The paper pot set $(6.5 \mathrm{~cm}$ depth $\times 1.5 \mathrm{~cm}$ diameter per pot) manufactured by Nippon Beet Sugar Co., Ltd., Kyushu, Japan, was filled with potting medium. The potting medium was amended with $0.32 \mathrm{~g}$ of ground barley grain inoculum of HBNR per pot. One surface-sterilized tomato seed was sown in each pot. The seedlings were allowed to grow for 21 days and then were transferred with the HBNR-amended soils to plastic pots $(10 \mathrm{~cm}$ depth $\times 12 \mathrm{~cm}$ diameter $)$ containing $500 \mathrm{~g}$ of $F$. oxysporum f. sp. radicis-lycopersici-infested potting medium, with a concentration of $1 \times 10^{5}$ spores per $g$ of soil. The plants were kept in the greenhouse for 70 days at 16 to $22^{\circ} \mathrm{C}$. Seedlings not treated with HBNR and challenged or not challenged with $F$. oxysporum f. sp. radicis-lycopersici were set up as controls. For each treatment, four replicates were made and each replicate consisted of four plants. Disease severity based on the foliar symptom was assessed using a scale of 0 to $4: 0=$ healthy plant, all leaves green; 1 = lower leaves yellow; 2 $=$ lower leaves wilted and some upper leaves yellow; $3=$ whole leaves wilted; $4=$ dead plant. Discoloration severity of vascular tissue/cortex/xylem was assessed subjectively after cutting the basal stem or crown of each plant as midpoint percentage on the following scale: $0=$ healthy (no vascular discoloration); $1=\leq 33 \%$ (midpoint $=16.5 \%$ ); $2=>33$ to $67 \%$ (midpoint $=50 \%$ ); $3=>67$ to $100 \%$ (midpoint $=$ $83.5 \%$ ). Discoloration of total root system caused by FCRR was recorded on three experiments of the greenhouse soil system only and was assessed as midpoint percentage on the following scale: $-=$ healthy $(0 \%) ;+=\leq 33 \%($ midpoint $=16.5 \%) ;++=$ $>33$ to $67 \%$ (midpoint $=50 \%) ;+++=>67$ to $100 \%$ (midpoint $=83.5 \%$ ). Three experiments were conducted during 1999 and 2000 using this system.

One additional experiment was carried out in the field during 2001 to 2002. The soil in the field was a sandy loam with $\mathrm{pH}$ 6.7. The soil was fumigated with chloropicrin (25 liters per $1,000 \mathrm{~m}^{2}$ ). Vinyl polypropylene was placed over the bed immediately after injection of the fumigant and left in place for 2 weeks. Twenty-eight days after fumigation, the soil was inoculated with a spore suspension of the pathogen with a sprinkling can. The initial pathogen inoculum in the field as determined by dilution plating technique using Komada's selective medium (21) was $5 \times$ $10^{2} \mathrm{CFU} / \mathrm{g}$ of soil. Seven days later, 35day-old tomato plants in paper pots with HBNR W1-amended soil were transplanted in the field. Tomato seedlings treated with HBNR W1 were prepared as follows. Twenty-one-day-old tomato seedlings in paper pots $(6.5 \times 1.5 \mathrm{~cm}$ diameter $)$ containing HBNR W1-amended potting medium (0.32 $\mathrm{g}$ of ground barley grain inoculum of HBNR per pot) were transferred to plastic pots $(9 \times 7.6 \mathrm{~cm})$ containing HBNR W1-amended potting medium (8 $\mathrm{g}$ of ground barley grain inoculum HBNR per pot) and were allowed to grow for another 14 days before transplanting in the field. Tomato plants were planted approximately $50 \mathrm{~cm}$ apart. Seedlings not treated with HBNR and challenged or not challenged with $F$. oxysporum f. sp. radicis-lycopersici were set up as controls. All treatments had four replicates, with five plants per replicate. Disease severity and discoloration severity were assessed as described previously. Tomato fruits were harvested, weighed, and graded from 70 to 133 days after transplanting. The marketable yield was calculated by summing the weights of fruit graded Gifu-Japan class A and class $\mathrm{B}$ : class $\mathrm{A}=>100 \mathrm{~g}$, class $\mathrm{B}=$ $>70$ to $100 \mathrm{~g}$ or elliptical shape. Other grades having less than $70 \mathrm{~g}$, irregular shape, or puffy or cracking fruit are unmarketable.

Assay of HBNR for control of FCRR in hydroponic rock wool system. Two sizes of cube, mini cube $(3.7 \times 3.7 \times 4 \mathrm{~cm})$ and large cube $(7.5 \times 7.5 \times 6.5 \mathrm{~cm})$ rock wool substrates (Grodan; Grodania A/S, Hedehusene, Denmark) were used. The substrates were autoclaved and inoculated with $25 \mathrm{ml}$ and $200 \mathrm{ml}$ of mycelial suspension of HBNR for mini cubes and large cubes, respectively. The inoculated substrates were incubated for 7 days at $25^{\circ} \mathrm{C}$. Tomato seeds were sown individually in HBNR-inoculated rock wool mini cubes and allowed to grow for 21 days in a growth chamber at $25^{\circ} \mathrm{C}$. Afterward, each mini cube with a tomato seedling was inserted into a large cube. Four experiments were made using this system during 2000 to 2002. In experiments 1 and 2, transplants were placed onto rock wool slabs $(18 \times 45 \times 7.5 \mathrm{~cm})$ in polypropylene boxes $(50 \times 50 \times 50 \mathrm{~cm})$. Plastic baskets $(38 \times 29$ $\times 13 \mathrm{~cm}$ ) were placed in the bottom of the boxes to make a space at the lower portion of the slabs. Tap water was added to the boxes up to the surface of the slabs. Plant fertilizers Nutricote 12-0-0-23 (NPKCa) and Nutricote 13-11-13 (NPK) (Asahikasei Co., Ltd., Osaka, Japan) were applied at concentrations of $4.3 \mathrm{~g}$ per plant and $19.2 \mathrm{~g}$ per plant, respectively, at the beginning of the experiments. Each box contained two rock wool slabs in which two tomato plants were inserted about $20 \mathrm{~cm}$ apart in each slab. After 7 days, a spore suspension of $F$. oxysporum $\mathrm{f}$. sp. radicis-lycopersici $(4.5 \times$ $10^{4}$ microconidia per $\mathrm{cm}^{3}$ ) was inoculated into each rock wool cube. As controls, rock wool blocks not treated with HBNR and challenged or not challenged with $F$. oxysporum f. sp. radicis-lycopersici were included. Four HBNR isolates (L2, W1, W7, and Rhv7) and 2 HBNR isolates (W1 and Rhv7) were used in experiments 1 and 2 , respectively. The experiments were conducted in the greenhouse for 91 days (experiment 1) and 140 days (experiment 2) at 16 to $23^{\circ} \mathrm{C}$. Experiments 3 and 4 were carried out in a manner similar to that of a standard commercial production system. The transplants were placed onto rock wool slabs $(18 \times 91 \times 7.5 \mathrm{~cm})$ in plastic sleeves. Each slab contained four tomato plants about $20 \mathrm{~cm}$ apart. In this system, the slabs were placed on the greenhouse floor. Tomato transplants grown in large 
cubes of rock wool were placed on the surface of the slabs over holes $(10 \times 10$ $\mathrm{cm})$ cut in the plastic sleeve. Nutrient solutions High-Tempo Ar and High-Tempo $\mathrm{Cu}$ (Taiyou Kogyou Co. Ltd., Tokyo, Japan) were provided continually through drip irrigation emitters placed at the base of each transplant. Excess nutrient solution drained out through slits cut in the bottom of the plastic sleeves. The rock wool slabs were maintained at saturation with nutrient solution at all times. After 7 days, a spore suspension of $F$. oxysporum $\mathrm{f}$. sp. radicislycopersici $\left(4.5 \times 10^{4}\right.$ microconidia per $\mathrm{cm}^{3}$ ) was inoculated into each rock wool cube. Rock wool cubes not treated with HBNR and challenged or not challenged with $F$. oxysporum f. sp. radicis-lycopersici were set up as controls. Two HBNR isolates (W1 and Rhv7) and one HBNR (W1) were used in experiments 3 and 4, respectively. The experiments were conducted for 93 days (experiment 3 ) and 180 days (experiment 4) after inoculation of pathogen at 16 to $23^{\circ} \mathrm{C}$. All treatments had four replicates, with four plants per replication.

Disease severity based on the foliar symptom of wilting was monitored for 63 to 91 days, 83 to 140 days, 74 to 93 days, and 60 to 180 days after inoculation with the pathogen in experiments $1,2,3$, and 4 , respectively. Discoloration severity of vascular tissue/cortex/xylem was assayed at the end of experiments. Tomato fruits were harvested, weighed, and graded from 100 to 180 days after transplanting. Disease severity, discoloration severity, and the marketable and total yields were calculated as described previously.

Monitoring of $F$. oxysporum f. sp. radicis-lycopersici and HBNR in stems and roots. Populations of $F$. oxysporum $\mathrm{f}$. $\mathrm{sp}$. radicis-lycopersici in the stems and roots were estimated at the end of experiment 3 in the greenhouse soil system and experiment 1 in the rock wool system. The stems ( 0 to $20 \mathrm{~cm}$ above soil surface) and whole root parts from all plants in each score were washed separately in tap water to remove adhering soils and combined. The stems or roots were added to sterile distilled water (1:10 wt/vol) and homogenized using a blender (Type $\mathrm{H}$, Teraoka Toyo Keisokuki Co., Ltd., Osaka, Japan) at $8,000 \mathrm{rpm}$ for 5 to $7 \mathrm{~min}$. The homogenized stems and roots were filtered through two layers of gauze, diluted 10- to 100fold, and plated on Komada's selective medium in six plates per replication (21). The number of colony forming units of $F$. oxysporum f. sp. radicis-lycopersici per gram fresh weight of stems or roots in each score, based on discoloration severity, within each treatment was recorded. Populations in each replication within the treatment were calculated using the formula $\left(P_{0} A+P_{1} B+P_{2} C+P_{3} D\right) / N \times 100$, where $P_{0,1,2 \text {, and } 3}=$ populations of pathogen in scores $0,1,2$, and 3 , respectively; $A=$ number of plants that score $0 ; B=$ number of plants that score 1; $C=$ number of plants that score $2 ; D=$ number of plants that score 3 ; and $N=$ total number of plants. Each treatment, consisting of four plants, was replicated four times.

Colonization of HBNR on roots was recorded at the end of experiment 2 in the greenhouse soil system, 70 days after inoculation of pathogen. Four plants were randomly sampled from each treatment. The roots were cut into three parts: (i) inside paper pot; (ii) 0 to $3 \mathrm{~cm}$ outside paper pot; and (iii) more than $3 \mathrm{~cm}$ away from paper pot. The roots from each part were washed with tap water, cut into $1-\mathrm{cm}$ sections, and combined. Combined sections were thoroughly stirred and rinsed three times in sterile distilled water. Ten root sections were randomly selected, blotted dry, and placed on acidified water agar ( $\mathrm{pH} 4.5$ ). After $48 \mathrm{~h}$ of incubation, fungal growth on the samples was examined visually and microscopically. The presence of HBNR was confirmed by its characteristic growth and the morphology of its mycelium. The experiment was replicated six times. Each replication consists of 10 root sections. Stem colonization by HBNR was also recorded at the end of experiment 2 in the soil system. All plants treated with HBNR were examined. The stems were washed with tap water, cut into 2- to 3-mm sections at $1,5,10,15$, and $20 \mathrm{~cm}$ above the soil surface, and then rinsed three times in sterile distilled water. The stem sections (four replicates, each replicate consisting of four stem sections) in each position were checked for the presence of HBNR using the same procedure as described above.

Effect of stem extracts on the germination and proliferation of $F$. oxysporum f. sp. radicis-lycopersici. The tomato plants treated with isolate HBNR W1 and Rhv7 were used. The stems were taken from experiment 1 in the rock wool system, 91 days after inoculation of the pathogen. The filtrates of homogenized stem were centrifuged at $4,100 \mathrm{rpm}$ for 10 min. The supernatant solutions were collected and filtered in $0.45-\mu \mathrm{m}$ Millipore (Millex-HV; Millipore Co., Bedford, MA). Two milliliters of stem extracts were placed in small petri dishes $(40 \times 20 \mathrm{~mm})$. Cellophane was then positioned on the surface of the extract and immediately 40 $\mu \mathrm{l}$ of spore suspension of $F$. oxysporum $\mathrm{f}$. sp. radicis-lycopersici $\left(5 \times 10^{5}\right.$ spores per $\mathrm{ml})$ was placed on the cellophane. Percent germination was determined by randomly counting 400 spores per petri dish. Germ tube lengths for 40 spores per petri dish were measured under the microscope. The effect of stem extracts on proliferation of the pathogen was evaluated by counting newly formed conidia in the stem extracts. Nine milliliters of stem extract and $1 \mathrm{ml}$ of spore suspension of $F$. oxysporum f. sp. radicis-lycopersici $\left(1 \times 10^{6}\right.$ spores per $\left.\mathrm{ml}\right)$ were mixed in a $100-\mathrm{ml}$ Erlenmeyer flask.
The flask was then incubated at room temperature $\left(25^{\circ} \mathrm{C}\right)$ on a reciprocal shaker at $150 \mathrm{rpm}$ for 24 days. The numbers of conidia were determined with a hemacytometer. Each petri dish and Erlenmeyer flask constituted one replicate. Each experiment was conducted four times.

Data analysis. The experiments in soil and rock wool systems were carried out in randomized complete block design with four replications, four to five plants per replication. First, variance analysis of treatment means obtained for discoloration severity, discoloration of total root system, population of pathogen, yield and effect of stem extracts on germination, and proliferation of pathogen was done, and when the $F$ test was significant, these means were compared using Duncan's multiple range test at $P=0.05$ and $P=0.01$. Discoloration severity and discoloration of total root system data in the soil and rock wool systems were analyzed after transformation to arcsine $\sqrt{x}_{x}$. Curvilinear regression was used to analyze the relationship between discoloration severity of vascular tissue/cortex/xylem in crown area and disease severity of foliar symptom from the combined data of soil and rock wool systems.

\section{RESULTS}

Assay of HBNR for control of FCRR of tomato in soil system. HBNR isolates L2, W1, W7, and Rhv7 were able to reduce FCRR disease of tomato caused by $F$. $o x$ ysporum $\mathrm{f}$. sp. radicis-lycopersici in the soil system under greenhouse conditions (Table 1). All HBNR isolates significantly $(P=0.01)$ reduced discoloration severity of vascular tissue/cortex/xylem in the three greenhouse experiments (Table 1). The reduction of discoloration severity by HBNR L2, W1, W7, and Rhv7 ranged from 90 to $96 \%, 95$ to $100 \%, 90$ to $100 \%$, and 90 to $100 \%$, respectively. HBNR-treated plants also showed significantly $(P=0.01)$ less discoloration of the total root system caused by FCRR in the three experiments conducted in the greenhouse (Table 1). The reduction of discoloration of total root system by HBNR L2, W1, W7, and Rhv7 ranged from 73 to $82 \%, 81$ to $82 \%, 81$ to $82 \%$, and 85 to $89 \%$, respectively.

The experiment conducted in the field also resulted in a significant $(P=0.05)$ reduction of discoloration severity of vascular tissue/cortex/xylem by $71 \%$ (Table $2)$. In addition, the number of marketable tomatoes significantly $(P=0.05)$ increased by $22 \%$ on plants treated with HBNR W1 compared with the pathogen only, but no significant increase was observed on the total yield. The weight of marketable or total yield also increased by 16 or $29 \%$, respectively, on treatment with HBNR W1 compared with the pathogen (Table 2), but no statistical significance was obtained.

Assay of HBNR for control of FCRR in hydroponic rock wool system. Tomato 
plants grown in the hydroponic rock wool system and treated with all HBNR isolates had lower discoloration and disease severities in all four experiments (Table 3, Fig. $1 \mathrm{~A}$ to $\mathrm{D})$.

All HBNR-treated plants, except L2 in experiment 1 , resulted in significant $(P=$ $0.05)$ reductions in discoloration severity of vascular tissue/cortex/xylem in all experiments (Table 3 ). The reductions of discoloration severity by HBNR L2, W1, W7, and Rhv7 were $50 \%, 24$ to $100 \%$, $57 \%$, and 18 to $100 \%$, respectively.

Plants treated with all HBNR isolates had lower disease severity compared with the pathogen treatment (Fig. 1). In experiment 1, HBNR isolates L2, W1, W7, and Rhv7 reduced disease severity of FCRR by 44 to $90 \%, 85$ to $100 \%, 85$ to $100 \%$, and
77 to $100 \%$, respectively (Fig. 1A). In experiment 2, applications of HBNR isolates $\mathrm{W} 1$ and Rhv7 also resulted in a reduction of disease severity (Fig. 1B). The greatest reduction occurred at 83 to 110 days, after which disease increased in both HBNR treatments. The disease severity reduction ranged from 41 to $100 \%$ and 47 to $100 \%$ for HBNR W1 and HBNR Rhv7, respectively. In experiments 3 and 4, the application of HBNR W1 and Rhv7, and HBNR W1, respectively, resulted in $100 \%$ disease reduction of FCRR throughout the experiments (Fig. 1C and D).

In experiment 4, application of HBNR $\mathrm{W} 1$ in a commercial rock wool system resulted in a significant $(P=0.05)$ increase in marketable and total yields of tomato by as much as 70 and $73 \%$, respectively, com-

Table 1. Effect of hypovirulent binucleate Rhizoctonia (HBNR) isolates on vascular discoloration severity and discoloration of total roots system due to Fusarium crown and root rot of tomato caused by Fusarium oxysporum f. sp. radicis-lycopersici in a greenhouse soil system

\begin{tabular}{|c|c|c|c|c|c|c|}
\hline \multirow[b]{3}{*}{ Treatments } & \multicolumn{3}{|c|}{$\begin{array}{c}\text { Discoloration severity } \\
(\%)^{\mathrm{w}}\end{array}$} & \multicolumn{3}{|c|}{$\begin{array}{c}\text { Discoloration } \\
\text { of total roots system }(\%)^{x}\end{array}$} \\
\hline & \multicolumn{6}{|c|}{ Experiments $^{\mathrm{y}}$} \\
\hline & 1 & 2 & 3 & 1 & 2 & 3 \\
\hline Control & $0.0 \mathrm{a}^{\mathrm{z}}$ & $0.0 \mathrm{a}$ & $0.0 \mathrm{a}$ & $0.0 \mathrm{a}$ & $0.0 \mathrm{a}$ & $0.0 \mathrm{a}$ \\
\hline $\begin{array}{l}\text { F. oxysporum f. sp. } \\
\text { radicis-lycopersici }\end{array}$ & $35.4 \mathrm{~b}$ & $29.9 \mathrm{~b}$ & $43.8 \mathrm{~b}$ & $54.2 \mathrm{c}$ & $43.3 \mathrm{~b}$ & $69.9 \mathrm{~b}$ \\
\hline HBNR L2 & $2.1 \mathrm{a}$ & $1.1 \mathrm{a}$ & $4.2 \mathrm{a}$ & $14.5 \mathrm{~b}$ & $9.9 \mathrm{a}$ & $12.4 \mathrm{a}$ \\
\hline HBNR W1 & $0.0 \mathrm{a}$ & $0.0 \mathrm{a}$ & $2.1 \mathrm{a}$ & $10.4 \mathrm{~b}$ & $7.7 \mathrm{a}$ & $13.5 \mathrm{a}$ \\
\hline HBNR W7 & $0.0 \mathrm{a}$ & $0.0 \mathrm{a}$ & $4.2 \mathrm{a}$ & $10.4 \mathrm{~b}$ & $7.7 \mathrm{a}$ & $12.5 \mathrm{a}$ \\
\hline HBNR Rhv7 & $0.0 \mathrm{a}$ & $0.0 \mathrm{a}$ & $4.2 \mathrm{a}$ & $6.2 \mathrm{ab}$ & $6.6 \mathrm{a}$ & $10.4 \mathrm{a}$ \\
\hline
\end{tabular}

${ }^{\mathrm{w}}$ Discoloration severity was assessed as midpoint percentage on the following scale: $0=$ healthy (no vascular discoloration); $1=\leq 33 \%$ (midpoint $=16.5 \%) ; 2=>33$ to $67 \%$ (midpoint $=50 \%) ; 3=>67$ to $100 \%$ (midpoint $=83.5 \%$ ) of discoloration of vascular tissue/cortex $/$ xylem.

${ }^{\mathrm{x}}$ Discoloration of total root system was assessed as midpoint percentage on the following scale: $-=$ healthy $(0 \%) ;+=\leq 33 \%$ (midpoint $=16.5 \%) ;++=>33$ to $67 \%$ (midpoint $=50 \%$ ); $+++=>67$ to $100 \%$ (midpoint $=83.5 \%$ ) of discoloration of total roots.

${ }^{y}$ HBNR-treated seedlings ( 21 day old) in experiments 1,2 , and 3 were transplanted into pathogeninfested soil on 9 October 1999, 31 March 2000, and 6 October 2000, respectively. Data were taken 70 days after inoculation with $F$. oxysporum f. sp. radicis-lycopersici.

${ }^{\mathrm{z}}$ Mean of four replications with four plants per replication. Values followed by the same letter in each column do not differ significantly $(P=0.01)$ according to Duncan's multiple range test. Data were analyzed after transformation to arcsine $\sqrt{ } x$.

Table 2. Effect of a hypovirulent binucleate Rhizoctonia (HBNR) isolate on discoloration severity of Fusarium crown and root rot of tomato caused by Fusarium oxysporum f. sp. radicis-lycopersici and on tomato yields in the field ${ }^{\mathrm{w}}$

\begin{tabular}{|c|c|c|c|c|c|}
\hline \multirow[b]{2}{*}{ Treatments } & \multirow{2}{*}{$\begin{array}{l}\text { Discoloration } \\
\text { severity }(\%)^{x}\end{array}$} & \multicolumn{2}{|c|}{ Marketable yield per planty } & \multicolumn{2}{|c|}{ Total yield per plant } \\
\hline & & Number & Weight (g) & Number & Weight (g) \\
\hline Control & $6.2 \mathrm{a}^{\mathrm{z}}$ & $8.3 \mathrm{a}$ & $1,746 \mathrm{a}$ & $45.3 \mathrm{a}$ & $8,790 \mathrm{a}$ \\
\hline $\begin{array}{l}\text { F. oxysporum f. sp. } \\
\text { radicis-lycopersici }\end{array}$ & $31.4 \mathrm{~b}$ & $9.7 \mathrm{a}$ & $1,783 \mathrm{a}$ & $36.3 \mathrm{a}$ & $5,366 \mathrm{a}$ \\
\hline HBNR W1 & $9.2 \mathrm{a}$ & $12.4 \mathrm{~b}$ & $2,129 \mathrm{a}$ & $40.5 \mathrm{a}$ & $7,531 \mathrm{a}$ \\
\hline
\end{tabular}

${ }^{\mathrm{w}}$ Treated seedlings (35 day old) were transplanted into artificially pathogen-infested field on 7 September 2001. Data were taken 133 days after inoculation of $F$. oxysporum f. sp. radicis-lycopersici. HBNR isolates were applied as barley grain inoculum. Control was seedling not treated with HBNR and not challenged with $F$. oxysporum f. sp. radicis-lycopersici.

${ }^{x}$ Discoloration severity was assessed as midpoint percentage on the following scale: $0=$ healthy (no vascular discoloration); $1=\leq 33 \%$ (midpoint $=16.5 \%) ; 2=>33$ to $67 \%$ (midpoint $=50 \%) ; 3=>67$ to $100 \%$ (midpoint $=83.5 \%$ ) of discoloration of vascular tissue/cortex $/$ xylem.

y The marketable yield was calculated by summing the weights of fruit graded Gifu-Japan class A and class $\mathrm{B}$ : class $\mathrm{A}=>101 \mathrm{~g}$, class $\mathrm{B}=>70$ to $100 \mathrm{~g}$ or elliptical shape. Other grades having less than $70 \mathrm{~g}$, irregular shape, puffy or cracking fruit are unmarketable.

${ }^{\mathrm{z}}$ Mean of four replications with five plants per replication. Values followed by the same letter in each column do not differ significantly $(P=0.05)$ according to Duncan's multiple range test. Data of disease severity were analyzed after transformation to arcsine $\sqrt{ } x$. pared with untreated plants challenged with $F$. oxysporum f. sp. radicis-lycopersici (Fig. 2A and B).

Discoloration severity of vascular tissue/cortex/xylem in the crown area significantly $(P=0.01)$ correlated with the disease severity of foliar symptom from the combined data of the soil and rock wool systems (Fig. 3). Curvilinear regression $(y$ $\left.=0.441 x^{2}-0.541 x+0.615, R^{2}=0.719\right)$ best described the relationship. Particularly, the correlation in the rock wool system was very high (Curvilinear regression: $y=0.0004 x^{2}+0.0005 x+0.001, R^{2}=$ $0.9362)$. However, in the soil system, significant correlation was not found (Curvilinear regression: $y=0.0016 x^{2}-0.0486 x+$ $\left.0.8012, R^{2}=0.3158\right)$.

Monitoring of $F$. oxysporum f. sp. radicis-lycopersici and HBNR in stems and roots. Tomato plants grown in the soil and rock wool systems, treated with all HBNR isolates except L2 and W7 in the roots of the rock wool system, had significantly $(P=0.05)$ lower $F$. oxysporum f. sp. radicis-lycopersici population densities in stems and roots (Table 4). In stems, population densities in the soil and rock wool system were significantly $(P=0.05)$ reduced by 95 to $97 \%$ and 80 to $97 \%$, respectively, in HBNR-treated plants. In roots, the reduction of population densities in the soil and rock wool systems of HBNRtreated plants ranged from 90 to $96 \%$ and 36 to $91 \%$, respectively.

In the soil system, HBNR isolates variously colonized (38 to $62 \%$ ) the root system in the paper pot where they were inoculated. Among the four HBNR isolates, the colonization ability of L2 was significantly $(P=0.05)$ lower than W1 and Rhv7, but was not significantly lower than W7 on the roots inside the paper pot. HBNR isolates could only colonize 7 to $15 \%$ and 3 to $12 \%$ of the root system at 0 to $3 \mathrm{~cm}$ and more than $3 \mathrm{~cm}$ away from paper pot, respectively, at 70 days after inoculation. The colonization abilities of four HBNR isolates in roots outside the paper pot were not significantly different from each other (Fig. 4). HBNR isolates were not obtained from the stem parts at $1,5,10,15$, or 20 $\mathrm{cm}$ above the soil surface.

Effect of stem extracts on the germination and proliferation of $\boldsymbol{F}$. oxysporum f. sp. radicis-lycopersici. Stem extracts from tomato plants treated with HBNR and challenged with the pathogen significantly $(P=0.01)$ inhibited spore germination and germling length of $F$. oxysporum f. sp. radicis-lycopersici. The effect of the extracts did not correlate with discoloration severity caused by $F$. oxysporum f. sp. radicis-lycopersici (Table 5). Spore germination and germling length were inhibited by 49 to $79 \%$ and 54 to $73 \%$, respectively, by stem extracts of HBNR-treated plants compared with that of untreated and unchallenged plants. The stem extract taken from plants inoculated only with $F$. 
Table 3. Effect of hypovirulent binucleate Rhizoctonia (HBNR) isolates on vascular discoloration severity due to Fusarium crown and root rot of tomato caused by Fusarium oxysporum f. sp. radicislycopersici in a rock wool system ${ }^{\mathrm{w}}$

\begin{tabular}{|c|c|c|c|c|}
\hline \multirow[b]{2}{*}{ Treatments } & \multicolumn{4}{|c|}{ Discoloration severity $(\%)^{x}$} \\
\hline & Experiment 1 & Experiment 2 & Experiment 3 & Experiment 4 \\
\hline Control & $0.0 \mathrm{a}^{\mathrm{y}}$ & $0.0 \mathrm{a}$ & $0.0 \mathrm{a}$ & $0.0 \mathrm{a}$ \\
\hline $\begin{array}{l}\text { F. oxysporum f. sp. } \\
\text { radicis-lycopersici }\end{array}$ & $83.5 \mathrm{~b}$ & $79.3 \mathrm{c}$ & $83.5 \mathrm{~b}$ & $79.3 \mathrm{c}$ \\
\hline HBNR L2 & $41.7 \mathrm{ab}$ & $\mathrm{ND}^{\mathrm{z}}$ & ND & ND \\
\hline HBNR W1 & $16.6 \mathrm{a}$ & $60.5 \mathrm{~b}$ & $0.0 \mathrm{a}$ & $33.3 \mathrm{~b}$ \\
\hline HBNR W7 & $36.1 \mathrm{a}$ & ND & ND & ND \\
\hline HBNR Rhv7 & $24.9 \mathrm{a}$ & $64.7 \mathrm{~b}$ & $0.0 \mathrm{a}$ & ND \\
\hline
\end{tabular}

${ }^{w}$ HBNR-treated seedlings (28 day old) grown in rock wool cube were challenge inoculated with $F$. oxysporum f. sp. radicis-lycopersici on 10 October 2000, 25 November 2000, 6 December 2000, and 11 October 2001 in experiments 1, 2, 3, and 4, respectively, and grown for 91 to 180 days. Data were taken 91 days, 140 days, 93 days, and 180 days after inoculation of $F$. oxysporum f. sp. radicis-lycopersici on the experiments $1,2,3$, and 4 , respectively.

${ }^{\mathrm{x}}$ Discoloration severity was assessed as midpoint percentage on the following scale: $0=$ healthy (no vascular discoloration); $1=\leq 33 \%$ (midpoint $=16.5 \%$ ) $; 2=>33$ to $67 \%$ (midpoint $50 \%$ ); $3=>67$ to $100 \%$ (midpoint $=83.5 \%$ ) of discoloration of vascular tissue/cortex/xylem.

${ }^{y}$ Mean of four replications with four plants per replication. Values followed by the same letter in each column do not differ significantly $(P=0.05)$ according to Duncan's multiple range test. Data were analyzed after transformation to arcsine $\sqrt{ } x$.

${ }^{\mathrm{z}} \mathrm{ND}=$ no data oxysporum f. sp. radicis-lycopersici did not significantly reduce spore germination and germling length.

The rate of budding cell formation increased rapidly during the first 7 days of incubation and declined thereafter when stem extracts of plants not treated and challenged or not challenged with pathogen were used (Fig. 5). On the contrary, when stem extracts of plants treated with HBNR isolates and challenged with pathogen were used, the rates of conidia formation were reduced throughout the experiment.

\section{DISCUSSION}

Results presented in this paper show the potential ability of HBNR isolates to protect tomato plants against $F$. oxysporum $\mathrm{f}$. sp. radicis-lycopersici in soil and hydroponic rock wool systems. HBNR isolates were consistently effective in reducing disease severity and discoloration severity throughout the experiments. They provided a high level of protection against FCRR
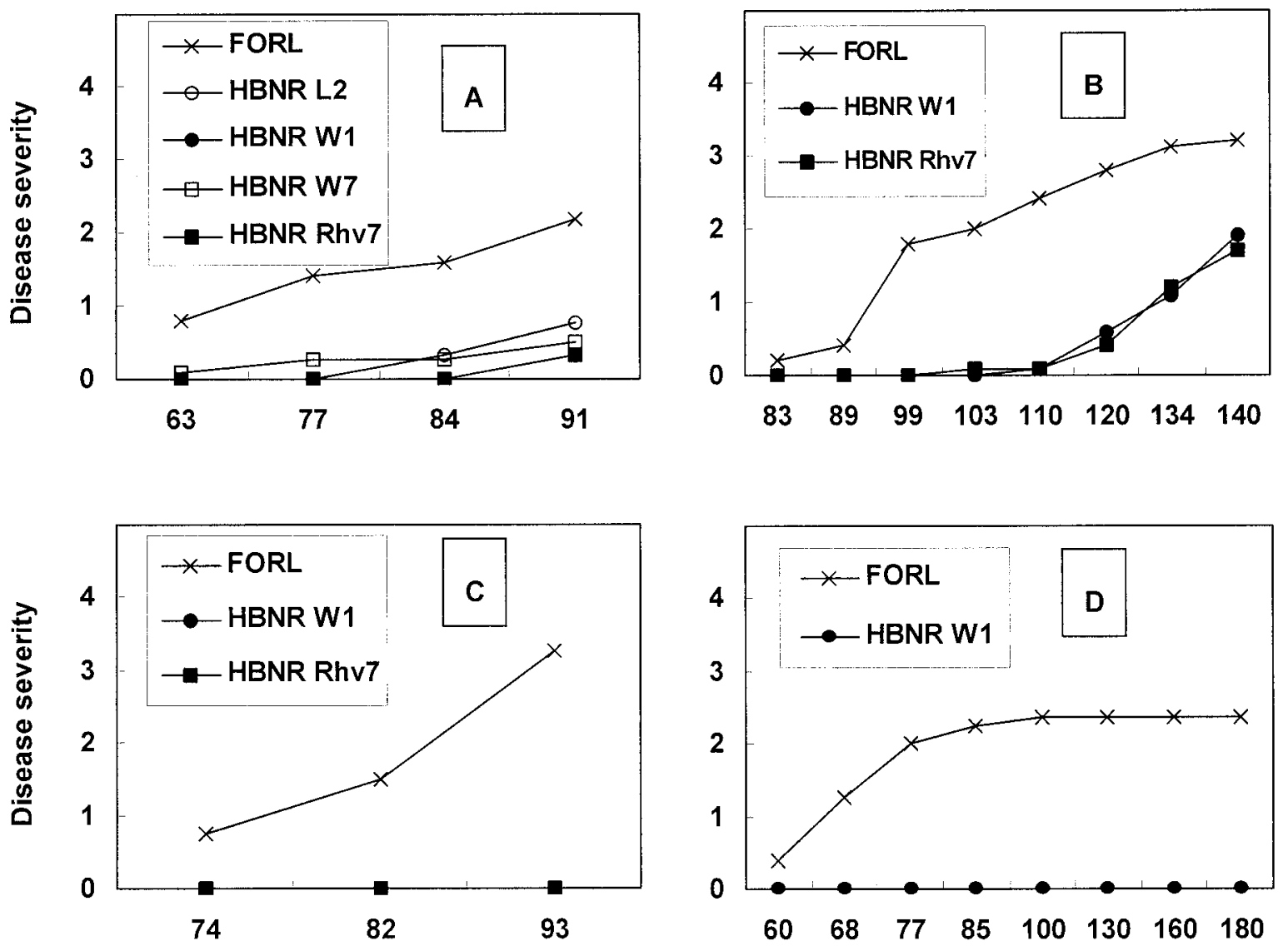

\section{Days after inoculation of pathogen}

Fig. 1. Disease progress of Fusarium crown and root rot caused by Fusarium oxysporum f. sp. radicis-lycopersici (FORL) based on foliar symptoms of wilting on tomato treated or not treated with a hypovirulent binucleate Rhizoctonia (HBNR) isolate under rock wool system in A, experiment 1, B, experiment 2, C, experiment 3, and $\mathbf{D}$, experiment 4 . Disease severity was assessed using a scale of 0 to 4 where: $0=$ healthy plant, all leaves green; $1=$ lower leaves yellow; $2=$ lower leaves wilted and some upper leaves yellow; $3=$ whole leaves wilted; and $4=$ dead plant. Data are means of four replications with four plants per replication. Bars represent standard error of the mean. Depending on experiment, the number of isolates of HBNR used was different. 
during the growing period in the soil and rock wool systems.

Marois et al. (27) reported the successful biological control of FCRR with multifun- gus conidial suspensions consisting of three isolates of Trichoderma harzianum, one of Penicillium fumiculosum, and one of Aspergillus ochraceus in infested soil
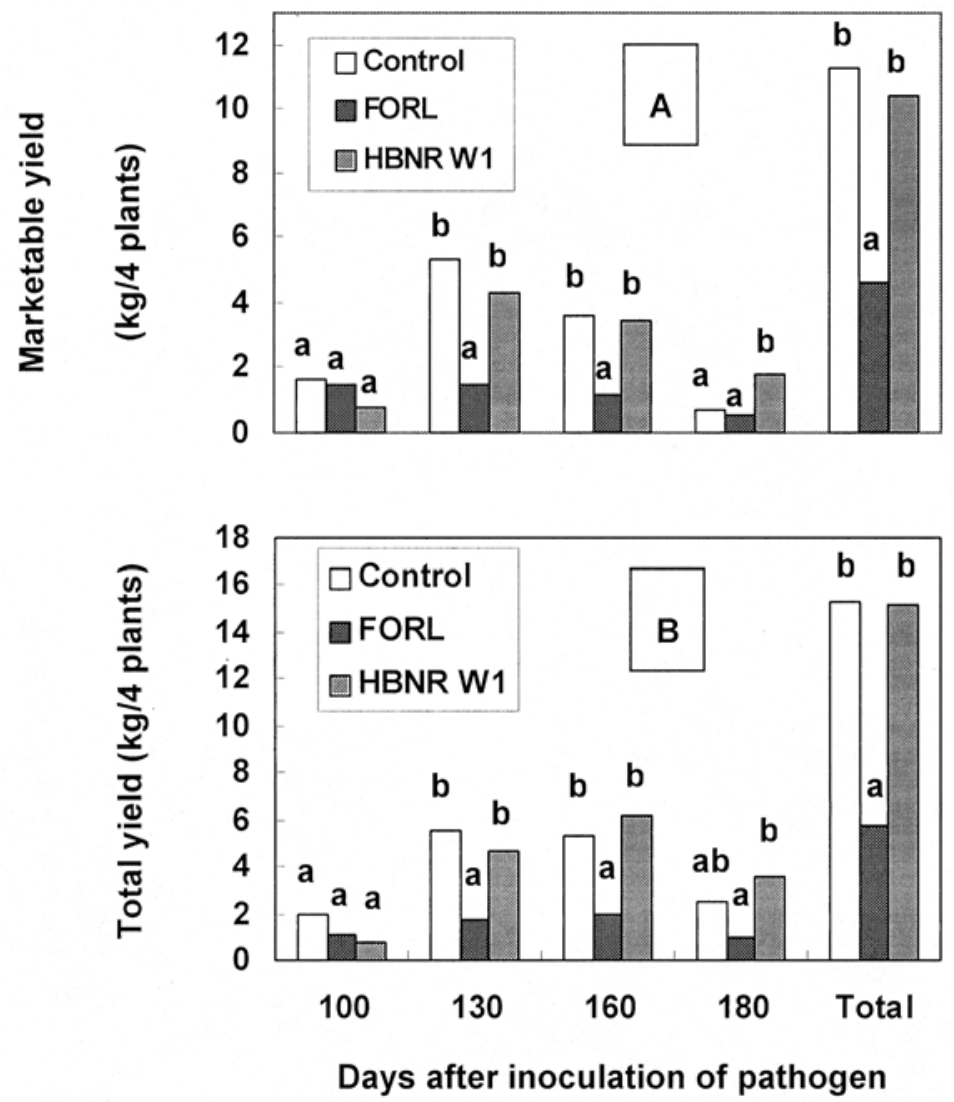

Fig. 2. Effect of biological control of Fusarium crown and root rot of tomato caused by Fusarium oxysporum f. sp. radicis-lycopersici (FORL) with a hypovirulent binucleate Rhizoctonia (HBNR W1) on A, marketable yield and $\mathbf{B}$, total yield at each harvest date in experiment 4 under rock wool system. Data are means of four replications with four plants per replication. Bars labeled with the same letter are not significantly different $(P=0.05)$ according to Duncan's multiple range test.

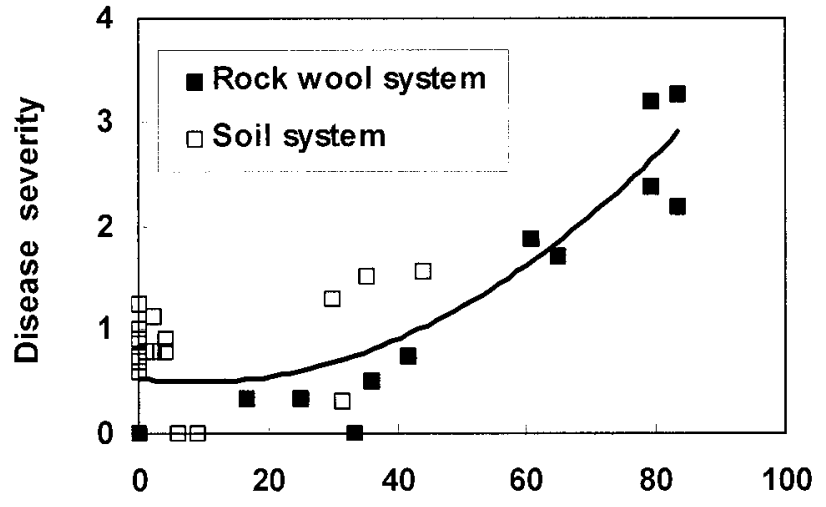

\section{Discoloration severity}

Fig. 3. Relationship between discoloration severity of vascular tissue/cortex/xylem in the crown area and disease severity of foliar symptoms of Fusarium oxysporum f. sp. radicis-lycopersici from the combined data of soil and rock wool system experiments. Data are means of four replications with four plants per replication. Curvilinear regression $\left(y=0.441 x^{2}-0.541 x+0.615, R^{2}=0.719, P=0.01\right)$ best described the relationships. Discoloration severity was assessed as midpoint percentage on the following scale: $0=$ healthy (no vascular discoloration); $1=\leq 33 \%$ (midpoint $=16.5 \%$ ); $2=>33$ to $67 \%$ (midpoint $=50 \%$ ); 3 $=>67$ to $100 \%$ (midpoint $=83.5 \%$ ) of discoloration of vascular tissue $/$ cortex $/ x y l e m$. Disease severity was assessed using a scale of 0 to 4 where: $0=$ healthy plant, all leaves green; $1=$ lower leaves yellow; 2 $=$ lower leaves wilted and some upper leaves yellow; $3=$ whole leaves wilted; and $4=$ dead plant.

with the pathogen at low concentration. Our study demonstrated that a single biological control agent of HBNR alone significantly reduced disease severity even under high pathogen inoculum pressure. Sivan et al. (39) also demonstrated that application of a single biological control agent, i.e., T. harzianum, could successfully reduce disease incidence of FCRR even under high pathogen concentration.

In the past, HBNR isolates have demonstrated the ability to control $R$. solani diseases in a variety of hosts and cropping systems $(4,5,16,18)$. Louter and Edgington (25) were the first to demonstrate the biological control of FCRR on tomato with binucleate Rhizoctonia sp. in seedling stage (24 days after sowing) in a growth pouch system. However, although it significantly reduced discoloration of roots, hypocotyls, or cortexes, the seedlings were stunted, with short, stubby roots. In this study, the HBNR isolates controlled FCRR throughout the growing season, in both soil and rock wool systems, and also increased the yield of tomato. In a previous study, the application of HBNR isolates L2, W1, and W7 as barley grain inocula resulted in significant control of Rhizoctonia damping-off of cucumber (46). Isolate HBNR Rhv7 applied as rice grain inocula significantly reduced banded leaf and sheath blight of corn caused by $R$. solani AG1-IA (34). In this study, the four HBNR isolates were applied as barley grain and mycelial suspensions, and effectively reduced FCRR caused by $F$. oxysporum f. sp. radicis-lycopersici. In the previous reports, HBNR also reduced damping-off in seedlings of Capsicum annuum and Celosia argentea caused by $P$. ultimum var. sporangiiferum (17) and black shank caused by Phytophthora parasitica var. nicotianae on greenhouse-grown tobacco seedlings in Styrofoam float trays (7).

Most of the studies have reported that HBNR isolates are effective in controlling damping-off diseases that attack plants at the seedling stage only $(4,5,18,46)$. However, based on our study, the protection effect of our HBNR isolates persisted for a long time against FCRR. These results expand the potential target range controlled by HBNR.

In this study, the discoloration severity of vascular tissue/cortex/xylem in the crown area significantly $(P=0.01)$ correlated with the disease severity of foliar symptoms, particularly in the rock wool system (Fig. 3). This result agreed with the report of Chambers and Corden (8), who reported that in Fusarium wilt disease of tomato, there was an association between the severity of vascular discoloration and the degree of foliar symptom (wilting and yellowing). In this study, however, a significant correlation was not observed in the soil system due to the very low disease severity of foliar symptoms (disease severity index ranged from 0 to 2 ). Yellowing 
was said to be usually associated with moderate vascular discoloration symptom, while wilting was associated with severe vascular symptom (8). In the soil system of this study, most plants showed slight disease with only yellowing of the lower leaves. The reason for not getting a significant correlation between discoloration severity and disease severity of foliar symptom in the soil system is that, even though the plants were not affected by the disease, they sometimes turned yellow. This indicates that there was a possibility that some of the yellowing observed was not caused by the disease but could be attributed to the aging of the plants.

The four HBNR isolates were similar in their ability to protect tomato plants against FCRR in all three experiments in the soil system. However, the efficacy of HBNR isolates used was significantly different in the rock wool system. In experiment 1 of the rock wool system, although isolates W1, W7, and Rhv7 significantly reduced discoloration severity, no significant reduction was observed in isolate L2. These results might be due to poorer root colonization by isolate $\mathrm{L} 2$ than by other isolates.

Application of HBNR isolates in the soil system resulted in a consistent and high biocontrol effect against vascular discoloration of FCRR compared with the rock wool system. The competition for space and nutrients between $F$. oxysporum f. sp. radicis-lycopersici and other soil microorganisms probably has contributed to low disease severity observed in the soil system since nonsterilized soil was used throughout the experiments. Therefore, the ability of HBNR in reducing FCRR was more effective under lower than higher disease pressure.

Among experiments conducted in the rock wool system (Fig. 1), there were great differences in disease control between experiments 1 and 2 and experiments 3 and 4. This might be due to the different levels of nutrients. In experiments 1 and 2, nutrients were applied only once during the experiments and were not enough to maintain plant growth throughout the test. This could have weakened the plants and made them more susceptible to FCRR. In experiments 3 and 4, nutrients were provided throughout the experiments, resulting in more vigorous plants. Even though infected (vascular discoloration), these plants may have been able to suppress the wilt symptoms. In the field soil system, even though plants were not challenged with the pathogen, they were infected with $F$. oxysporum f. sp. radicis-lycopersici, probably due to incomplete soil sterilization.

In the present study, preinoculation of tomato seedlings with HBNR not only suppressed disease severity but also reduced pathogen populations in the roots and stems. This suggests that although $F$. oxysporum f. sp. radicis-lycopersici can infect the tomato roots, it will not be able to develop and spread in the plants. Results of the present study support previous reports where application of nonpathogenic F. oxysporum Fo47 and Pseudomonas putida WCS 358 decreased the population of pathogenic $F$. oxysporum in roots of flax, which contributed to disease suppression (13). Benhamou et al. (1) reported that prior inoculation of tomato root with $P$. oligandrum induced the formation of structural barriers that protected the inner root tissue from $F$. oxysporum f. sp. radicislycopersici invasion and prevented pathogen spread. Nelson et al. (32) also reported that preinoculation of tomato and cucumber with nonpathogenic Fusarium species reduced frequency of isolation of pathogenic formae specialis. Similar results were obtained for resistant varieties, where the Fusarium population in stems and roots was significantly lower than that of susceptible cultivars in tomato $(14,43)$ and in the

Table 4. Effect of hypovirulent binucleate Rhizoctonia (HBNR) isolates on population densities of Fusarium oxysporum f. sp. radicis-lycopersici in tomato stems and roots under soil and rock wool systems $^{\mathrm{y}}$

\begin{tabular}{|c|c|c|c|c|}
\hline \multirow[b]{3}{*}{ Treatments } & \multicolumn{4}{|c|}{ Population of pathogen $\left(\times 10^{3} \mathrm{CFU} / \mathrm{g}\right.$ fresh weight $)$} \\
\hline & \multicolumn{2}{|c|}{ Soil system } & \multicolumn{2}{|c|}{ Rock wool system } \\
\hline & Stem & Root & Stem & Root \\
\hline $\begin{array}{l}\text { F. oxysporum f. sp. } \\
\text { radicis-lycopersici }\end{array}$ & $1.06 \mathrm{~b}^{\mathrm{z}}$ & $31.48 \mathrm{~d}$ & $1.40 \mathrm{c}$ & $98.00 \mathrm{~b}$ \\
\hline HBNR L2 & $0.05 \mathrm{a}$ & $1.14 \mathrm{a}$ & $0.28 \mathrm{~b}$ & $62.64 \mathrm{ab}$ \\
\hline HBNR W1 & $0.04 \mathrm{a}$ & $3.16 \mathrm{c}$ & $0.04 \mathrm{a}$ & $8.94 \mathrm{a}$ \\
\hline HBNR W7 & $0.04 \mathrm{a}$ & $2.43 \mathrm{bc}$ & $0.17 \mathrm{ab}$ & $56.31 \mathrm{ab}$ \\
\hline HBNR Rhv7 & $0.04 \mathrm{a}$ & $1.79 \mathrm{ab}$ & $0.05 \mathrm{a}$ & $23.49 \mathrm{a}$ \\
\hline
\end{tabular}

${ }^{y}$ Data were recorded at the end of experiment 3 in the greenhouse soil system (70 days after inoculation of pathogen) and experiment 1 in the rock wool system (91 days after inoculation of pathogen).

${ }^{\mathrm{z}}$ Data are means of four replications. Values followed by the same letter in each column do not differ significantly $(P=0.05)$ according to Duncan's multiple range test.

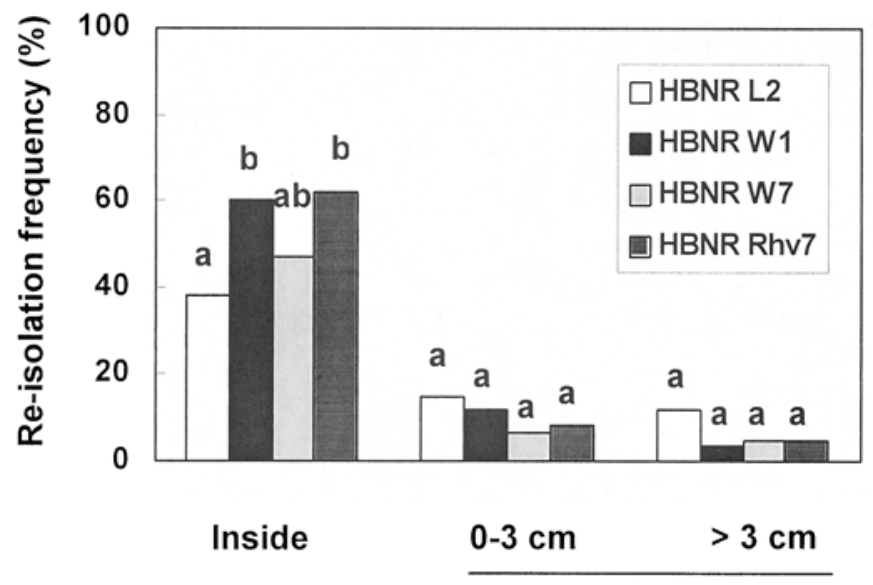

paper pot

\section{Outside paper pot}

Fig. 4. Isolation of hypovirulent binucleate Rhizoctonia (HBNR) isolates from roots inside and outside paper pots. Plants were taken from experiment 2 in the greenhouse soil system. HBNR isolates were applied as barley grain inoculum ( $0.32 \mathrm{~g}$ of ground barley grain inoculum of HBNR per pot) to soil in paper pots. Pots were surrounded by soil infested with Fusarium oxysporum f. sp. radicislycopersici. Assays were performed 70 days after inoculation of the pathogen. Data are the means of 6 replications with 10 root sections per replication. Bar values with the same letter are not significant according to Duncan's multiple range test. 
lic compound creating a fungitoxic environment to $F$. oxysporum $\mathrm{f}$. $\mathrm{sp}$. radicislycopersici. Piga et al. (35) also reported that preinoculation of tomato with $\mathrm{Pseu}$ domonas fluorescens induced the accumulation of electron-dense material in intercellular space that frequently surrounded hyphae of $F$. oxysporum f. sp. radicislycopersici. Hyphae coated with this material were distorted and exhibited marked changes, including increased vacuolation, cytoplasm disorganization, and cell breakdown. In addition, Stromberg and Corden (43) reported that the xylem extract from a resistant tomato cultivar inoculated with the Fusarium wilt pathogen was highly fungitoxic to the growth of the pathogen. Previous studies reported that inhibition of the pathogen in roots and stems of resistant tomato cultivars after inoculation with the Fusarium wilt pathogen was related to the accumulation of tomatine and rishitin $(15,23,26)$.

If an antagonist and pathogen are closely related, it is likely that they might compete for the same nutrients and infection sites (41). However, the fact that binucleate Rhizoctonia can also control FCRR caused by $F$. oxysporum f. sp. radicis-lycopersici, which is not closely related to Rhizoctonia, suggests that a mechanism other than competition for an ecological niche may be important. Additionally, we did not observe hyperparasitism, hyphal interference, nor an antibiosis between HBNR isolates L2, $\mathrm{W} 1, \mathrm{~W} 7$, and Rhv7 and F. oxysporum f. sp.

Table 5. Effect of stem extracts from plants treated with hypovirulent binucleate Rhizoctonia (HBNR) isolates on spore germination and germling length of Fusarium oxysporum f. sp. radicislycopersici ${ }^{\mathrm{x}}$

\begin{tabular}{lccc}
\hline Treatments & $\begin{array}{c}\text { Discoloration } \\
\text { severity }(\%)^{\mathbf{y}}\end{array}$ & $\begin{array}{c}\text { Germination } \\
(\%)^{\mathbf{z}}\end{array}$ & $\begin{array}{c}\text { Germling length } \\
(\boldsymbol{\mu m})^{\mathbf{z}}\end{array}$ \\
\hline $\begin{array}{l}\text { Control } \\
\text { Fusarium oxysporum f. sp. }\end{array}$ & 0 & $52.0 \mathrm{c}$ & $17.0 \mathrm{~b}$ \\
$\quad$ radicis-lycopersici & 83.5 & $45.0 \mathrm{c}$ & $16.0 \mathrm{~b}$ \\
HBNR W1 & 0 & $11.0 \mathrm{a}$ & $4.6 \mathrm{a}$ \\
HBNR W1 & 50 & $11.5 \mathrm{a}$ & $4.8 \mathrm{a}$ \\
HBNR Rhv7 & 0 & $26.8 \mathrm{~b}$ & $7.8 \mathrm{a}$ \\
HBNR Rhv7 & 83.5 & $19.3 \mathrm{ab}$ & $6.4 \mathrm{a}$ \\
\hline
\end{tabular}

${ }^{x}$ Stem samples were taken from experiment 1 in rock wool system, 91 days after inoculation of $F$ oxysporum f. sp. radicis-lycopersici. Stem extracts were prepared from the filtrates of homogenized stems showing different discoloration severity. Depending on treatment, the number of plants in each score of the stem extracts ranged from 0 to 16 .

${ }^{\mathrm{y}}$ Discoloration severity was assessed as midpoint percentage on the following scale: $0=$ healthy (no vascular discoloration); $1=\leq 33 \%$ (midpoint $=16.5 \%) ; 2=>33$ to $67 \%$ (midpoint $=50 \%$ ); $3=>67$ to $100 \%$ (midpoint $=83.5 \%$ ) of discoloration of vascular tissue/cortex $/$ xylem.

${ }^{\mathrm{z}}$ Germination and germling length were determined after $12 \mathrm{~h}$ incubation. Data are means of four replications with 400 and 40 spores per replication for germination and germling length, respectively. Values followed by the same letter in each column do not differ significantly $(P=0.01)$ according to Duncan's multiple range test.

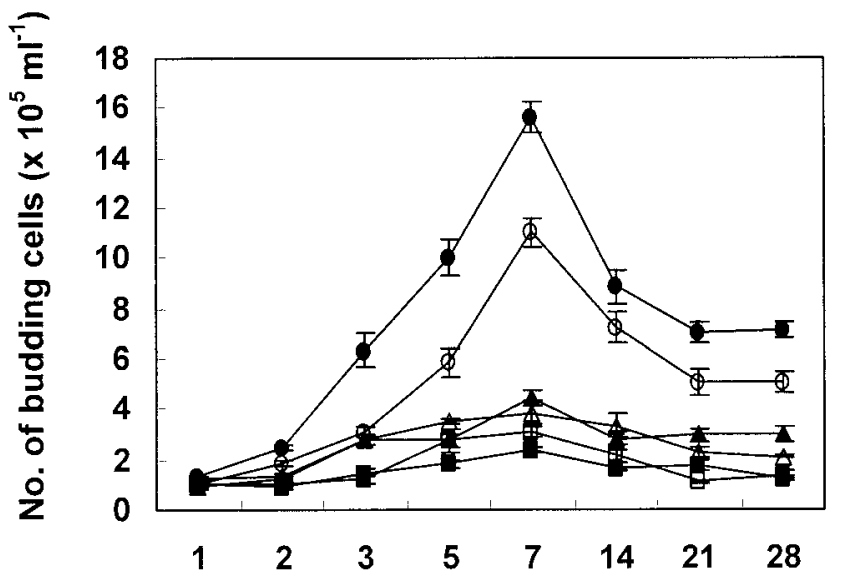

Time (days)

Fig. 5. Effect of stem extracts on the production of budding cells of Fusarium oxysporum f. sp. radicis-lycopersici. Stem extracts were taken from experiment 1 in rock wool system and collected 91 days after inoculation of pathogen. Stem extracts of plants came from control $(\bigcirc), F$. oxysporum

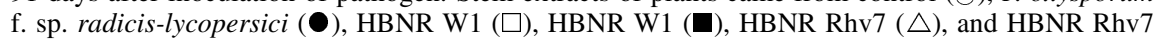
(ム) treatments showing scores of $0,83.5,0,50,0$, and $83.5 \%$ of vascular discoloration severity, respectively. HBNR isolates were hypovirulent binucleate Rhizoctonia fungi. The experiment was replicated four times. radicis-lycopersici in vitro (unpublished data) and, as also reported by other workers $(6,40)$, the hypovirulent Rhizoctonia did not inhibit or parasitize $R$. solani. Another possible mechanism is induced resistance, as suggested by Cardoso and Echandi (6) that competition might not be the only mechanism involved in the protection of bean seedlings treated with HBNR against Rhizoctonia root rot caused by $R$. solani.

Biocontrol agents in contact with plant roots could induce resistance, which is transferred to whole roots, stems, or leaves. Such resistance occurs when the plant is protected locally or systemically on different parts by application of an inducing agent and the pathogen $(2,10)$. In the soil system where HBNR and the pathogen were inoculated at separate sites, HBNR was re-isolated easily from the site where it was inoculated, but was reisolated much less frequently from the roots outside the paper pot where the soil was infested with the pathogen only. Furthermore, HBNR was not re-isolated from the tomato stem, indicating that the hyphae of HBNR did not move from the roots to the stems. These findings suggest that, in this system, induced resistance may be one of the mechanisms of biocontrol of FCRR with HBNR.

A major constraint to the practical use of biocontrol agents is the narrow range of target pathogens that they can effectively control. However, the fact that the HBNR isolates control not only related pathogens but also unrelated pathogens, i.e., $F$. oxysporum f. sp. radicis-lycopersici (31), $P$. ultimum var. sporangiiferum (17), and $P$. parasitica var. nicotianae (7), gives great promise for their use as biocontrol agents. HBNR isolates are promising biocontrol agents due to their ubiquitous occurrence, nonpathogenic nature, aggressive colonization of root and soil, and tolerance of a wide range of environmental conditions $(4,6,9,28)$. Further research is needed to determine what mechanisms are involved in disease control with the HBNR system and to develop methods for the practical use of HBNR as biocontrol agents.

\section{ACKNOWLEDGMENTS}

We thank Onwona-Agyeman Siaw and Villa Joselito Evangelista for correcting the English in the manuscript. We also thank T. Suzuki, N. Katsuyama, and H. Narita from the Gifu Prefectural Research Institute for Agricultural Sciences for their technical assistance. The senior author (AM) thanks the Ministry of Education, Science, Sports, and Culture (Monbukagakusho) Japan, for financial assistance.

\section{LITERATURE CITED}

1. Benhamou, N., Rey, P., Cherif, M., Hockenhull, J., and Tirilly, Y. 1997. Treatment with the mycoparasite Pythium oligandrum triggers induction of defense-related reactions in tomato roots when challenged with Fusarium oxysporum f. sp. radicis-lycopersici. Phytopathology 87:108-122.

2. Biles, C. L., and Martyn, R. D. 1989. Local 
and systemic resistance induced in watermelons by formae speciales of Fusarium oxysporum. Phytopathology 79:856-860.

3. Brandt, W. H., Lacy, M. L., and Horner, C. E. 1984. Distribution of Verticillium in stem of resistant and susceptible species of mint. Phytopathology 74:587-591

4. Burpee, L. L., and Goulty, L. G. 1984. Suppression of brown patch disease of creeping bentgrass by isolates of nonpathogenic Rhizoctonia spp. Phytopathology 74:692-694.

5. Cardoso, J. E., and Echandi, E. 1987. Biological control of Rhizoctonia root rot of snap bean with binucleate Rhizoctonia-like fungi. Plant Dis. 71:167-170.

6. Cardoso, J. E., and Echandi, E. 1987. Nature of protection of bean seedlings from Rhizoctonia root rot by a binucleate Rhizoctonia-like fungus. Phytopathology 77:1548-1551.

7. Cartwright, D. K., and Spurr, H. W., Jr. 1998. Biological control of Phytophthora parasitica var. nicotianae on tobacco seedlings with non-pathogenic binucleate Rhizoctonia fungi. Soil Biol. Biochem. 30(14):1879-1884.

8. Chambers, H. L., and Corden, M. E. 1963. Semeiography of Fusarium wilt of tomato. Phytopathology 53:1006-1010.

9. Cubeta, M. A., Echandi, E., and Gumpertz, M. L. 1991. Survival of binucleate Rhizoctonia species, biological control agents, in soil and plant debris under field conditions. Biol. Control 1:218-226.

10. De Cal, A., Pascual, S., and Melgarejo, P. 1997. Involvement of resistance induction by Penicillium oxalicum in the biocontrol of tomato wilt. Plant Pathol. 46:72-79.

11. Dekker, J. 1979. Acquired resistance to fungicides. Annu. Rev. Phytopathol. 14:405-428.

12. Duffy, B. K., and Defago, G. 1997. Zinc improves biocontrol of Fusarium crown and root rot of tomato by Pseudomonas fluorescens and represses the production of pathogen metabolites inhibitory to bacterial antibiotic biosynthesis. Phytopathology 87:1250-1257.

13. Duijff, B. J., Recorbet, G., Bakker, P. A. H. M., Loper, J. E., and Lemanceau, P. 1999. Microbial antagonism at the root level is involved in the suppression of Fusarium wilt by the combination of nonpathogenic Fusarium oxysporum Fo47 and Pseudomonas putida WCS358. Phytopathology 89:1073-1079.

14. Elgersma, D. M., MacHardy, W. E., and Beckman, C. H. 1972. Growth and distribution of Fusarium oxysporum f. sp. lycopersici in near-isogenic lines of tomato resistant and susceptible to wilt. Phytopathology 62:12321237.

15. Hammerchlag, F., and Mace, M. E. 1975. Antifungal activity of extracts from fusarium wilt-susceptible and -resistant tomato plants. Phytopathology 65:93-94.

16. Harris, A. R., Schisler, D. A., Neate, S. M., and Ryder, M. H. 1994. Suppression of damping-off caused by Rhizoctonia solani, and growth promotion, in bedding plants by binucleate Rhizoctonia spp. Soil Biol. Biochem. 26:263-268.

17. Harris, A. R., Schisler, D. A., and Ryder, M. H. 1993. Binucleate Rhizoctonia isolates control damping-off caused by Pythium ultimum var. sporangiiferum, and promote growth in
Capsicum and Celosia seedlings in pasteurized potting medium. Soil Biol. Biochem. 25:909-914.

18. Ichielevich-Auster, M., Sneh, B., Koltin, Y., and Barash, I. 1985. Suppression of dampingoff caused by Rhizoctonia species by a nonpathogenic isolate of $R$. solani. Phytopathology 75:1080-1084.

19. Jarvis, W. R., and Shoemaker, R. A. 1978. Toxonomic status of Fusarium oxysporum causing foot and root rot of tomato. Phytopathology 68:1679-1680.

20. Kato, M., Amano, S., and Taguchi, Y. 1998. Research of tomato soil-borne diseases in hydroponic culture. Proc. Kansai Plant Prot. (40):97-98.

21. Komada, A. 1975. Development of a selective medium for quantitative isolation of Fusarium oxysporum from natural soil. Rev. Plant Prot. Res. (Tokyo) 8:114-125.

22. Lacy, M. L., and Horner, C. E. 1966. Behavior of Verticillium dahliae in the rhizosphere and on roots of plants susceptible, resistant, and immune to wilt. Phytopathology 56:427-430.

23. Langcake, P., Drysdale, R. G., and Smith, H. 1972. Post-infectional production of an inhibitor of Fusarium oxysporum f. sp. lycopersici by tomato plants. Physiol. Plant Pathol 2:17-25.

24. Leary, J. V., and Endo, R. M. 1971. A Fusarium-induced root rot of staked tomatoes. (Abstr.) Phytopathology 61:900.

25. Louter, J. H., and Edgington, L. V. 1990. Indication of cross-protection against fusarium crown and root rot of tomato. Can. J. Plant Pathol. 12:283-288.

26. MacCane, D. J., and Drysdale, R. B. 1975. Production of tomatine and rishitin in tomato plants inoculated with Fusarium oxysporum $\mathrm{f}$. sp. lycopersici. Physiol. Plant Pathol. 7:221230

27. Marois, J. J., Mitchell, D. J., and Sonoda, R. M. 1981. Biological control of fusarium crown rot of tomato under field condition. Phytopathology 71:1257-1260.

28. Martin, S. B., Campbell, C. L., and Lucas, L. T. 1983. Horizontal distribution and characterization of Rhizoctonia spp. in tall fescue turf. Phytopathology 68:145-148.

29. McGovern, R. J., Vavrina, C. S., Noling, J. W., Datnoff, L. A., and Yonce, H. D. 1998. Evaluation of application methods of metam sodium for management of Fusarium crown and root rot in tomato in southwest Florida. Plant Dis. 82:919-923.

30. Mihuta-Grimm, L., Erb, W. A., and Rowe, R. C. 1990. Fusarium crown and root rot of tomato in greenhouse rock wool systems: Sources of inoculum and disease management with benomyl. Plant Dis. 74:996-1002.

31. Muslim, A., Horinouchi, H., Kageyama, K., and Hyakumachi, M. 2001. Suppression of crown/root rot of tomato caused by Fusarium oxysporum f. sp. radicis-lycopersici by isolates of hypovirulent binucleate Rhizoctonia. (Abstr.) Jpn. J. Phytopathol. 67:190.

32. Nelson, H., Ouchi, S., Shiraishi, T., and Oku, H., 1992. Induced resistance to fusarium wilt of tomato and cucumber: Symptoms and pathogen proliferation. Ann. Phytopathol. Soc. Jpn. 58:659-663.
33. Ogura, H., and Ban, M. 1971. Fusarium oxysporum caused tomato wilt disease. II. Existence of $F$. oxysporum causes tomato wilt disease attended with root rot. Res. Rep. Kochi Univ., Agric. Sci. 20:71-77.

34. Pascual, C. B., Raymundo, A. D., and Hyakumachi, M. 2000. Efficacy of hypovirulent binucleate Rhizoctonia sp. to control banded leaf and sheath blight in corn. J. Gen. Plant Pathol. 66:95-102.

35. Piga, P. M., Belanger, R. R., Paulitz, T. C., and Benhamou, N. 1997. Increased resistance to Fusarium oxysporum f. sp. radicislycopesici in tomato plants treated with the endophytic bacterium Pseudomonas fluorescens strain 63-28. Physiol. Mol. Plant Pathol. 50:301-320.

36. Rowe, R. C., and Farley, J. D. 1977. New greenhouse tomato disease can be controlled Ohio Rep. 62:41-43.

37. Sato, R., and Araki, T. 1974. On the tomato root-rot disease occurred under vinyl-house conditions in southern Hokkaido. Ann. Rep. Soc. Plant Prot. N. Jpn. 25:5-13.

38. Scott, J. W., and Jones, J. P. 2000. Fla. 7775 and Fla. 7781: Tomato breeding lines resistant to Fusarium crown and root rot. HortScience 35(6):1183-1184

39. Sivan, A., Ucko, O., and Chet, I. 1987. Biological control of Fusarium crown rot of tomato by Trichoderma harzianum under field condition. Plant Dis. 71:587-592.

40. Sneh, B., Ichielevich-Auster, M., and Plaut, Z. 1989. Mechanism of seedling protection induced by a hypovirulent isolate of Rhizoctonia solani. Can. J. Bot. 67:2135-2141.

41. Sneh, B., Ichielevich-Auster, M., and Shomer, I. 1989. Comparative anatomy of colonization of cotton hypocotyls and roots by virulent and hypovirulent isolates of Rhizoctonia solani. Can. J. Bot. 67:2142-2149.

42. Sneh, B., Zeidan, M., Ichielevich-Auster, M Barash, I., and Koltin, Y. 1986. Increased growth responses induced by non-pathogenic Rhizoctonia solani. Can. J. Bot. 64:2372 2378 .

43. Stromberg, E. L., and Corden, M. E. 1977. Fungitoxicity of xylem extracts from tomato plants resistant or susceptible to Fusarium wilt. Phytopathology 67:693-697.

44. Summer, D. R., and Bell, D. K. 1994. Survival of Rhizoctonia spp. and root diseases in a rotation of corn, snap bean, and peanut in microplots. Phytopathology 84:113-118.

45. Villajuan-Abgona, R. 1995. Application of hypovirulent Rhizoctonia spp. for biological control of Rhizoctonia damping-off disease of cucumber and its associated mechanism. $\mathrm{Ph}$.D. thesis. United Graduate School of Agricultural Science, Science of Biological Environment, Gifu University, Japan.

46. Villajuan-Abgona, R., Kageyama, K., and Hyakumachi, M. 1996. Biocontrol of Rhizoctonia damping-off of cucumber by nonpathogenic binucleate Rhizoctonia. Eur. J. Plant Pathol. 102:227-235.

47. Xue, L., Charest, P. M., and Jabaji-Hare, S. H 1998. Systemic induction of peroxidases, 1,3$\beta$-glucanases, chitinases, and resistance in bean plants by binucleate Rhizoctonia species. Phytopathology 88:359-365 